\title{
Microsponges: A de novo Method for Colon Targeted Oral Drug Delivery
}

\author{
Kuralla Hari*, Sunkara Sai Prathyusha, Gokavarapu Vasavi \\ Department of Pharmaceutical Technology, Maharajah's College of Pharmacy, Phool Baugh, Vizianagaram, Andhra Pradesh, INDIA.
}

\begin{abstract}
Colon Targeted Oral Drug Delivery System has gained much importance in recent times in delivering drug substance for the local action against colonic cancers, infections, Ulcerative Colitis (UC) and Crohn's disease and for systemic action of protein peptides and non-peptide drugs include Cardiovascular and Antiasthamatics etc. This article gives an overview about the anatomy, physiology of colon and factors that are having influence on the formulation. Various approaches for colon targeting are specified and micro sponges are at forefront having unique, versatile and novel approach. Micro sponges are highly cross linked porous polymeric microspheres with many interconnected voids loaded with API that are released in a controlled manner. Micro sponges are designed to deliver efficiently at minimum dose with reduced side effects, enhancing the stability and solubility of active
\end{abstract}

pharmaceutical ingredients. Further, the novel techniques in preparation, compiling the present research information with novel applications of drug delivery with micro sponges are highlighted.

Key words: Crohn's disease, Nanosponges, Quasi emulsion, Ulcerative Colitis, Colon, Targeting, Delivery systems.

\section{Correspondence}

\section{Dr. Kuralla Hari}

Department of Pharmaceutical Technology, Maharajah's College of Pharmacy, Phool Baugh, Vizianagaram-535002 Andhra Pradesh, INDIA.

Phone no: +91 9880776163

Email: kuralla0205@gmail.com

DOI: 10.5330/ijpi.2020.3.44

\section{INTRODUCTION}

Colon-specific oral drug-delivery systems gained prominence in recent years. It helps to deliver diverse drug moieties for local as well as systemic action. ${ }^{1}$ The oral route of administration of drugs is well-established and is considered to have high patient compliance. Colon as a site specific for drug delivery has favourable position for, close neutral $\mathrm{pH}$, reduced gastric related enzymatic action, longer transit time and enhanced responsiveness to drug absorption. ${ }^{2}$

\section{Therapeutic advantages of Oral-Colon targeting:}

- Highly desirable in treating local diseases such as ulcerative colitis, amoebiasis, Crohn's disease, carcinoma and infections, while minimising the side effects that occur due to release of higher drug content in gastrointestinal tract or because of unnecessary systemic absorption. ${ }^{1}$

- Useful in chronotherapeutic point of view in delivery of those drugs where a delay in drug release is required, as in case of nocturnal asthma, angina pectoris, rheumatoid arthritis. ${ }^{1}$

- Avoid premature drug release in upper GIT. They are designed to selectively release the drug in response to the colonic environment. ${ }^{3}$

- $\quad$ Prevents the drug loss from first pass effect.

\section{Anatomy of Colon}

Large intestine is the final section in gastrointestinal tract comprises of caecum colon, rectum and anal canal which is extended from the ileocaecal junction to the anus as shown in Figure $1 .{ }^{4}$

Caecum seamlessly joins up with the colon. Colon is the largest portion of about 1.5 meters long, made up of ascending colon which continue as the transverse colon at hepatic flexure, then as the descending colon at splenic flexure and finally transformed as the sigmoid colon. ${ }^{4}$ Distal to ileocaecal sphincter, the bacterial concentration increases sharply and colon has micro flora of $10^{11}-10^{12} \mathrm{cfuml}^{-1} .^{5}$

Factors Effecting Colonic Drug Delivery are colonic fluid volume, intestinal colonic transit time, viscosity of colonic luminal contents, colonic $\mathrm{pH}$, enzymes and metabolism. ${ }^{6}$

\section{Colonic Fluid Volume}

Although colon is considered to be having high water absorbing capacity, the fluid volume available in colon estimated to be 1-44 $\mathrm{ml}$. The average volume is approx. $13 \mathrm{ml}$ where, solubility and dose of the drug becomes an important factor for bioavailability in colon.

For example, a highly potent drug Budesonide having a dose of $9 \mathrm{mg}$ is well absorbed in the colon whereas mesalamine even though significantly have higher solubility $(3.64 \mathrm{mg} / \mathrm{ml})$ when compared to budesonide $(0.24$ $\mathrm{mg} / \mathrm{ml}$ ) its absorption at colon becomes rate limiting factor because of having significantly higher dose i.e., $4.8 \mathrm{~g}$ daily. ${ }^{6}$

\section{Intestinal Colonic Transit Time}

Colonic disease states like ulcerative colitis and Crohn's disease influence transit time. ${ }^{11}$ For example patients suffering from UC will have reduced colonic transit time results in reduced exposure to the distal colon this may affect the bioavailability of the drugs in colon. ${ }^{6}$

\section{Viscosity of Colonic Luminal Contents}

Viscous colonic contents and decreased intestinal motility restricts fluid movement around the dosage forms and retards dissolution. Reduced motility delays erosion of the drug products. ${ }^{7}$

\section{Colonic $\mathrm{pH}$, enzymes and metabolism}

In GIT region $\mathrm{pH}$ differs greatly from 1-2 in stomach to 7.5 in distal region of small intestine. 
$\mathrm{pH}$ declines from the farther region of small intestine to colon and increase gradually in colon as mentioned in Table $1 .{ }^{2,8}$

Colon $\mathrm{pH}$ influence the solubility of the drugs in colonic fluid which will have an effect on pharmacokinetic and pharmacodynamic behaviour of colonic drug delivery systems (CDDS). ${ }^{6}$ Some evidence suggests that there is substantial changes in gastrointestinal $\mathrm{pH}$ are associated with disease like cystic fibrosis, IBD, UC. ${ }^{9}$

Colon is known to consist over 400 different species of aerobic and anaerobic micro-organisms. ${ }^{6}$ These bacteria contain several hydrolytic and reductive metabolising enzymes. ${ }^{10}$ These enzymes helps in metabolising/ fermenting substance like carbohydrates and proteins. Micro flora activated systems are formulated with polysaccharides such as chitosan, guargum, pectin are promising rate controlling components in colon targeted dosage form. Colon targeting has two approaches Primary and Novel approach as mentioned in Table $3 .{ }^{10}$

\section{Release triggering mechanism of drug}

There are four mechanisms which trigger the drug release is discussed below in Figure 2. ${ }^{11}$

1. $\mathbf{p H}$ dependent release: $\mathrm{pH}$ varies along the GIT so dissolution of the polymer at desired site. This can be achieved by using the polymers that have a threshold $\mathrm{pH}$ (Table 2) for dissolution at that particular site.

2. Time dependent release: Time-dependent formulations are designed to release drug after desired lag time.

E.g. Delayed release drugs or therapy of disease that depends on circadian rhythms

3. Pressure based drug release: In the large intestine, mass peristaltic movements occur 3-4 times in a day for a short duration, resulting in temporary increase in luminal pressure in colon. Basing on this principle pressure controlled systems are designed. The use of gastrointestinal pressure has been proposed as a method of target release in the distal gut.

4. Drug release by colonic micro flora: The micro floral enzyme activity provides site specific drug release. E.g. Micro flora activated system that are formulated using non-starch polysaccharide like pectin, remain undigested in stomach as well as small intestine and only degrade by the anaerobic bacteria that are available in colon and thus release the drug.

Much emphasis has been laid recent times on the development of multi particulate dosage forms. Due to the small size and the uniform dispersion, multi particulate system (MPS) easily pass through the GIT and results in increased drug absorption. MPS approach enables the drug to reach the colon rapidly and can retain for a long duration. ${ }^{1}$ These MPS include coated pellets, granules, micro particles and nanoparticle that can be converted into a dosage form either by filling into a gelatin capsule or compressed into tablets. These dosage forms can provide modified drug release. Hence, this system is preferred over single unit dosage forms like tablets. ${ }^{12}$

In this context, micro sponges are at forefront having unique, versatile and novel approach. ${ }^{13}$ It represents a new model of porous polymeric microspheres, which allows the entrapment of a wide range of active moieties. ${ }^{14}$ This promising system has its application in transdermal, oral, ocular, pulmonary and parenteral delivery of bioactive compounds. ${ }^{15} \mathrm{In}$ the present review, microsponges are considered as a de novo method for colon drug targeting.

"Microsponges delivery system (MDS) also known as solid phase porous microsphere. Microsponges (MS) are highly cross linked, porous polymeric structures, having many inter connected voids impregnated with an active ingredient releasing controlled manner" ${ }^{16} \mathrm{MS}$ are colloidal in nature and size ranges from 5-300 $\mu \mathrm{m}$ in diameter. A typical $25 \mu \mathrm{m}$ sphere may have up to $2,50,000$ pores and each micro pore comprises a total pore volume of approx., $1 \mathrm{ml} / \mathrm{g}$ and pore length equiv. $10 \mathrm{ft}$ which results in extensive drug retention. MS method was invented by Richard Won in 1987. The original patents were assigned to Advanced Polymer Inc. $^{16}$

MS act as carriers. Drug entrapment by carrier system results in reduction in particle size, increases active surface area and thus enhances solubilisation. ${ }^{17}$ MDS possess various attractive features given below. ${ }^{18}$

- Stability over wide range of $\mathrm{pH} 1-11$ and can withstand up to $130^{\circ} \mathrm{C}$.

- Higher payload of 50 to $60 \%$ and cost effective.

- Self-sterilization property as the pore size is $0.25 \mu \mathrm{m}$ where bacteria cannot penetrate.

- Unique dissolution and compressional properties. ${ }^{19}$

- Can be tailored to have controlled release as per need by further incorporating into tablets, capsules, creams, gels, lotions and powders.

\section{Properties of drug}

For drug entrapment into micro sponges, the bioactive should fulfil the following criteria. ${ }^{20}$

- It must be fully miscible with selected polymer and water immiscible.

- It should be inert and stable during the process of polymerization.

- Should not increase the viscosity of the mixture during formulation. ${ }^{18}$

\section{Mechanism of Action}

MS having the size of $<200 \mu \mathrm{m}$ may efficiently be taken up by the macrophages that are present in the colon. Thus they exhibit effective localised drug action at the desired site. They can increase lag time for absorption of the drug as these get intact on to the mucosal surface of colon and thus they have the potential for being developed as colon targeted drug delivery. ${ }^{16}$

\section{Novel Drug Carrier Systems with their limitations}

- Microcapsules - Once the wall get ruptured, the rate of drug release cannot be controlled. ${ }^{21}$

- Liposomes - Lower payload capacities, limited chemical stability, microbial instability and rapid drug leakage. ${ }^{21}$

- Solid lipid nanoparticles - have insufficient stability, sterilization problem. $^{22}$

- Microspheres and Nano particles - Comparative to micro sponges they are non-porous in nature and have less capability to bind to rough surface of intestinal mucosa..$^{23}$

\section{METHODS FOR PREPARATION OF MICROSPONGES}

(1) Liquid liquid suspension polymerization

(2) Quasi emulsion solvent diffusion (QESD)

Liquid-liquid suspension polymerization method: An organic solution prepared using monomer or monomers (combination), a polymerization catalyst, drug which are fully miscible in an inert organic solvent. This organic solvent is suspended in an aqueous solution which contains additives like suspending agents and surfactants to promote the suspension. Polymerization of the reactants was activated using the temperature or by irradiation. Upon completion of the process the rigid porous solid structures were recovered. The pores are formed as a result of the removal of immiscible organic solvent. ${ }^{24}$ 
Note: Drug loading may be of two steps when the drug is sensitive to the polymerization condition, the polymerization is performed using the substitute porogen and is replaced by the functional substance under mild experimental condition. ${ }^{24}$ Schematic representation of the process is shown in Figure 3..$^{24,25}$

"Quasi emulsion solvent diffusion"25 technique: Internal organic phase when dispersed in aqueous phase it forms the globules; further diffusion of solvent results in leaving the structure porous. The detailed description is given below with schematic representation in Figure 4. ${ }^{25}$

- Preparation of Internal phase: It is an organic solution formed by dissolving drug, polymer and plasticizer in a miscible inert organic solvent. If necessary it is sonicated..$^{25}$

- Preparation of external aqueous phase contains an emulsifier like PVA is generally used to maintain the stability. ${ }^{25}$

The organic solution is added drop wise into the aqueous solution and mixed by using stirrer that provides the mechanical shear results in formation of globules. Stirring is continued until a rigid porous solid

Table 1: pH at various regions of GI tract.

\begin{tabular}{lcc}
\hline & Region of Gl tract & $\mathrm{pH}$ \\
\hline & Stomach & $1.5-3$ (fasted), $2-$ \\
Small intestine & Duodenum & $5(\mathrm{fed})$ \\
& Jejunum & 6.1 (fasted), $\approx 5.4$ (fed) \\
Large intestine & Ileum & 6.4 \\
& Caecum & $7-8$ \\
& Ascending colon & 5.5 \\
& Transverse colon & 5.7 \\
& Descending colon & 7.6 \\
& Sigmoid colon, rectum anal canal & $7-8$ \\
\hline
\end{tabular}

Table 2: pH of commonly used polymers.

\begin{tabular}{cccc}
\hline Polymer & $\mathrm{pH}$ & Polymer & $\mathrm{pH}$ \\
\hline Eudragit L 100 & 6.0 & $\begin{array}{c}\text { Hydroxypropylmethylcellulose } \\
\text { (HPMC) phthalate }\end{array}$ & 4.8 \\
Eudragit S 100 & 7.0 & HPMC phthalate 50 & 5.2 \\
Eudragit FS 30D & 6.8 & HPMC phthalate 55 & 5.4 \\
Eudragit L 30D & 5.6 & Cellulose acetate trimellitate & 4.8 \\
$\begin{array}{c}\text { Eudragit L 100-55 } \\
\begin{array}{c}\text { Polyvinyl acetate } \\
\text { phthalate }\end{array}\end{array}$ & 5.5 & Cellulose acetate phthalate & 5.0 \\
\hline
\end{tabular}

Table 3: Systems of drug delivery to colon.

\begin{tabular}{ll}
\multicolumn{1}{c}{ Primary Approach } & \multicolumn{1}{c}{ Novel Approach } \\
\hline $\begin{array}{ll}\text { 1. Coating drug with pH sensitive } \\
\text { polymer }\end{array}$ & 1. Pressure Controlled (PCDDS) \\
2. Delayed release & 2. Novel Colon Targeted Delivery \\
3. Microbially triggered & Systems. \\
a. Prodrug approach & 3. Osmotic Controlled \\
b. Azo polymeric prodrug & 4. Pulsatile \\
c. Polysaccharide based systems & a. Pulsincap \\
& b. Port System \\
& 5. Azo Hydrogels \\
& 6. Multiparticulate drug delivery \\
\hline
\end{tabular}

particles i.e., MS is formed. They are recovered by filtering through Whatman filter paper $0.45 \mu \mathrm{m}$ and are washed to remove the solvent residues, further dried in an air heated oven at $40^{\circ} \mathrm{C}$ for $12 \mathrm{~h}{ }^{17}$ or vacuum oven at $40^{\circ} \mathrm{C}$ for $24 \mathrm{~h}^{25}$

Generally used materials are

*Solvents: Ethyl Alcohol or Dichloromethane or Acetone or Methanol.

*Plasticizers: Tri Ethyl Citrate or Dibutyl Phthalate.

*Polymer: Eudragit, ethyl cellulose, styrene.

${ }^{*}$ Emulsifiers: polyvinyl alcohol.

\section{Limitations}

The organic solvents used in the process pose an environmental and safety hazard because of flammability of some solvents. The traces of residual solvent is observed in case of bottom up approach and are toxic and hazardous and this can be overcome by employing appropriate quality control measures, process standardization and proper washing after post manufacture. ${ }^{16}$

Table 4: Effect of variables in the formulation.

\begin{tabular}{|c|c|c|}
\hline Variable & Effects & Reference \\
\hline $\begin{array}{l}\text { Drug to } \\
\text { polymer } \\
\text { ratio }\end{array}$ & $\begin{array}{l}\text { DP ratio has its affect on } \\
\text { the particle size. }\end{array}$ & $\begin{array}{c}\text { Vivekanand K Chatap et al. } 2018 \\
\text { found increase in DP ratio resulted } \\
\text { in particle size reduction. }{ }^{28}\end{array}$ \\
\hline $\begin{array}{c}\text { Stirring } \\
\text { speed }\end{array}$ & $\begin{array}{l}\text { Low speed leads to form } \\
\text { agglomerate and high } \\
\text { shear rate causes the } \\
\text { breakdown of globules } \\
\text { resulting in irregular } \\
\text { shape. }\end{array}$ & $\begin{array}{c}\text { Mine orlu et al. } 2006 \text { found } 350-450 \\
\text { rpm caused to form fibrous and } \\
\text { aggregates whereas at } 500 \mathrm{rpm} \\
\text { produces smaller particle size and } \\
\text { homogenous distribution. Optimum } \\
\text { speed of } 500 \mathrm{rpm} \text { spherical shape } \\
\text { was found. }{ }^{29}\end{array}$ \\
\hline $\begin{array}{l}\text { Stirring } \\
\text { time }\end{array}$ & $\begin{array}{l}\text { The optimum time } \\
\text { required for formation } \\
\text { of MS }\end{array}$ & $\begin{array}{l}\text { M Orlu et al. } 2006 \text { observed that } \\
\text { solidification of MS one hour } \\
\text { stirring is required for preparing } \\
\text { microsponges. }{ }^{29}\end{array}$ \\
\hline \multirow[t]{2}{*}{$\begin{array}{l}\text { Stirring } \\
\text { types }\end{array}$} & \multirow{2}{*}{$\begin{array}{l}\text { Mechanical stirrer with } \\
\text { 3to } 4 \text { bladed propellers, } \\
\text { centrifugal stirrer } \\
\text { are used to provide } \\
\text { mechanical shear that } \\
\text { results in formation of } \\
\text { the globules. }\end{array}$} & $\begin{array}{l}\text { M Orlu et al. } 2006 \text { found aggregates } \\
\text { were formed when 3-4 bladded } \\
\text { propeller were used. }\end{array}$ \\
\hline & & $\begin{array}{l}\text { Aggregate amount is low with } 2 \\
\text { bladed centrifugal stirrer. }\end{array}$ \\
\hline \multirow[t]{3}{*}{$\begin{array}{l}\text { Volume } \\
\text { internal } \\
\text { phase }\end{array}$} & \multirow{3}{*}{$\begin{array}{l}\text { Optimum volume 3-5 } \\
\text { ml. } \\
\text { Used to dissolve the } \\
\text { drug, polymer and } \\
\text { forms the organic phase. }\end{array}$} & $\begin{array}{l}\text { M Orul et al. } 2006 \text { found that Milky } \\
\text { phase formed with high amount } \\
\text { of internal phase solvent of } 5 \text { and } \\
10 \mathrm{ml} \text {. }\end{array}$ \\
\hline & & $\begin{array}{l}\text { The microsponges could be } \\
\text { prepared by decreasing amount of } \\
\text { ethyl alcohol to } 3 \mathrm{ml}^{29}\end{array}$ \\
\hline & & $\begin{array}{l}\text { Kiwashima et al. } 1992 \text { described that } \\
\text { recovery of microsponges decreased } \\
\text { sharply with increase in ethyl } \\
\text { alcohol amount. }{ }^{30}\end{array}$ \\
\hline Emulsifier & $\begin{array}{l}\text { Helps to stabilise the } \\
\text { emulsion }\end{array}$ & $\begin{array}{l}\text { Sonali et al. } 2014 \text { found increasing } \\
\text { in concentration of emulsifier } \\
\text { resulted in formation of large } \\
\text { irregular shaped MS. }{ }^{27}\end{array}$ \\
\hline Plasticizer & $\begin{array}{l}\text { Provide the plasticity to } \\
\text { microsponges. }\end{array}$ & $\begin{array}{l}\text { Vivekanand K Chatap et al. } \\
2018 \text { observed that increase in } \\
\text { the concentration of plasticizer } \\
\text { increases the drying rate of } \mathrm{MS}^{28}\end{array}$ \\
\hline
\end{tabular}


Other Preparation Techniques that Recently Developed: Some of the novel techniques which are useful in preparing the porous microspheres are mentioned below. ${ }^{26}$

- Double emulsion solvent diffusion method (w/o/w): Preparation of biodegradable porous microspheres using water in oil in water technique.

Advantage: Efficient for loading water soluble and water insoluble drugs. This can be used to entrap thermo labile materials such as proteins and peptides.

Disadvantage: Using the water insoluble surfactants might result as residues in resultant microsponges.

- Addition of porogen: In this technique, internal aqueous phase contains porogen like hydrogen peroxide or sodium bicarbonate or sodium chloride. ${ }^{23}$

Advantage: Results in the formation of highly porous structure that are evenly distributed.

Disadvantage: May cause the disruption in structure.

- Oil in oil emulsion solvent diffusion: Volatile organic liquid used in the internal phase and oil (corn or mineral oil) as an external phase. The Volatile organic liquid was allowed to evaporate slowly with continuous stirring thus results in formation of MS.

Advantage: Surfactant traces were not present
Disadvantage: to remove the organic solvents vigorous washings must be carried out

- Lyophilization: In this method, the microspheres that were formed subjected for lyophilisation to form the pores.

Advantage: quick and rapid results.

Disadvantage: Might result in cracking or shrinkage of particles because of rapid removal of solvent.

- Vibrating orifice aerosol generator (VOAG) methodIt is a technique in which the surfactant was evaporated from the formed microdroplets leaving behind the porous structure

Advantage: This can be used in targeted drug delivery

Disadvantage: Requires reflux conditions.

- Ultrasound-assisted production: It is a modified method of liquidliquid suspension polymerization.

Where it utilise the $\beta$-cyclodextrin and diphenyl carbonate as the polymers and cross linking agent respectively. Size was controlled by heating and sonicating the reaction mixture. This resulted in formation of porous microspheres.

Advantage: Quick reproducible results.

Disadvantage: Irregular structure and may result in entrapment of potentially toxic cross linking agents.

\begin{tabular}{|c|c|c|c|}
\hline S.No & Product Name & Active ingredient with its therapeutic action & Manufacturer \\
\hline 1. & $\begin{array}{l}\text { Glycolic Acid Moisturizer w/ } \\
\text { SPF } 15\end{array}$ & $\begin{array}{l}\text { Glycolic Acid stimulate collagen synthesis which helps } \\
\text { to reduces wrinkles }\end{array}$ & $\begin{array}{l}\text { AMCOL Health and } \\
\text { Beauty Solution }\end{array}$ \\
\hline 2. & Retin A Micro & Tretinoin helps in treating Acne vulgaris & $\begin{array}{l}\text { Ortho-McNeil } \\
\text { Pharmaceutical, }\end{array}$ \\
\hline 3. & Carac Cream, $0.5 \%$ & $\begin{array}{l}\text { Fluorouracil useful in treating Actinic keratosis a } \\
\text { precancerous skin condition }\end{array}$ & $\begin{array}{l}\text { Dermik Laboratories, Inc. } \\
\text { Berwyn, PA } 19312 \text { USA }\end{array}$ \\
\hline 4. & $\begin{array}{l}\text { Line Eliminator Dual Retinol } \\
\text { Facia Treatment }\end{array}$ & $\begin{array}{c}\text { Retinol (Vitamin A) rejuvenate skin and reduces the } \\
\text { wrinkles }\end{array}$ & Avon \\
\hline 5. & Micro peel plus / Acne peel & $\begin{array}{l}\text { Salicylic acid Stimulates cells turnover, helps to improve } \\
\text { pigmentation and fine lines }\end{array}$ & Biomedic \\
\hline 6. & Retinol 15 Night cream & $\begin{array}{c}\text { Retinol (Vitamin A) rejuvenate skin and reduces the } \\
\text { wrinkles }\end{array}$ & Sothys \\
\hline 7. & Retinol cream & Retinol (Vitamin A) keeps the skin healthy. & Biomedic \\
\hline 8. & EpiQuin Micro & $\begin{array}{l}\text { Hydroquinone, Retinol both help in treatment of Hyper } \\
\text { pigmentation, also reduces skin irritation }\end{array}$ & SkinMedica Inc \\
\hline 9. & $\begin{array}{c}\text { Sports cream RS, Sports cream } \\
\text { XS }\end{array}$ & Acts as anagesic and Anti-inflammatory & Embil Pharmaceutical \\
\hline 10. & Salicylic Peel 20 and 30 & Salicylic acid results in Excellent exfoliation & Biophora \\
\hline \multirow[t]{2}{*}{11.} & Oil free matte block SPF 20 & $\begin{array}{l}\text { Presence Vinyl dimethicone, corn starch absorbs oil } \\
\text { from the skin. }\end{array}$ & Dermalogica \\
\hline & & Protects skin from UV rays (Sunscreen) & \\
\hline 12. & $\begin{array}{l}\text { Lactrex }^{\mathrm{nt}} 12 \% \text { Moisturizing } \\
\text { Cream }\end{array}$ & $\begin{array}{c}\text { Lactic acid, glycerine provides long lasting } \\
\text { Moisturization to skin }\end{array}$ & $\begin{array}{c}\text { SDR Pharmaceuticals, } \\
\text { Inc., Andover NJ, USA } \\
07821\end{array}$ \\
\hline 13. & Oil Control Lotion & $\begin{array}{c}\text { Controls the oil by absorption and also act as Skin } \\
\text { protectant }\end{array}$ & Fountain Cosmetics \\
\hline 14. & Ultra Guard & $\begin{array}{c}\text { Dimethicone helps in Protecting babies skin from } \\
\text { diaper rash }\end{array}$ & Scott Paper Company \\
\hline 15. & Aramis fragrance & $\begin{array}{l}\text { Ultra light powder that can sustain release fragrance } \\
\text { used in Anti perspirant spray }\end{array}$ & Aramis Inc. \\
\hline
\end{tabular}


Table 6: Research work on Microsponges drug formulations targeting to colon.

\begin{tabular}{|c|c|c|c|c|c|c|}
\hline S. No & Drug & Category & Method & Polymers used & Remarks & Ref \\
\hline 1. & Aspirin & NSAID & $\begin{array}{l}\text { Quasi emulsion solvent } \\
\text { diffusion (QESD) } \\
\text { method }\end{array}$ & Eudragit RS100 & $\begin{array}{l}\text { Sustained drug release, Reducing side } \\
\text { effects }\end{array}$ & 41 \\
\hline 3. & Acyclovir & Anti-cancer & QESD & Eudragit RS100 & Controlled drug release & 51 \\
\hline 4. & Albendazole & Anti protozoal & $\mathrm{O} / \mathrm{O}$ emulsion & Eudragit RS100 & Sustained release & 52 \\
\hline 5. & $\begin{array}{l}5 \text { Amino salicylic } \\
\text { acid/ mesalamine }\end{array}$ & $\begin{array}{l}\text { Anti- inflammatory to } \\
\text { treat IBD }\end{array}$ & QESD & $\begin{array}{l}\text { Eudragit S100, L100, } \\
\text { RS100 }\end{array}$ & $\begin{array}{l}\text { Enhanced bio availability of drug } \\
\text { targeting to colon }\end{array}$ & 53 \\
\hline 6. & Carvidilol & Anti- hypertensive & Novel method & Eudragit RS 100 & $\begin{array}{l}\text { Avoid first pass metabolism, enhance } \\
\text { the solubility }\end{array}$ & 54 \\
\hline 8. & Curcumin & Treatment for UC & QESD & $\begin{array}{l}\text { Eudragit } \\
\text { L100 }\end{array}$ & $\begin{array}{l}\text { Enhanced solubility site specific } \\
\text { Colon targeting }\end{array}$ & 23 \\
\hline 9. & Curcumin & Anti- inflammatory & QESD & Ethyl cellulose & $\begin{array}{c}\text { Enhanced solubility site specific } \\
\text { Colon targeting }\end{array}$ & 56 \\
\hline 10. & Diclofenac sodium & NSAID & QESD & $\begin{array}{l}\text { Eudragit L100, RS 100, } \\
\text { EPO } 100\end{array}$ & $\begin{array}{c}\text { Enhanced solubility and bio } \\
\text { availability }\end{array}$ & 57 \\
\hline 11. & Dicyclomine & Anti-Cholinergic & QESD & Eudragit RS 100 & $\begin{array}{l}\text { Prolonged drug release, } \\
\text { Effective local action. }\end{array}$ & 58 \\
\hline 12. & Dicyclomine & Anti- Cholinergic & QESD & Eudragit S100 & Colon targeting. & 59 \\
\hline 13. & Diltiazem & Anti- hypertensive & QESD & Eudragit RS100 & Controlled release & 60 \\
\hline 17. & 5 Fluoro Uracil & Anti cancer & $\begin{array}{l}\text { Modified QESD using } \\
\text { porogen }\end{array}$ & Eudragit RS100 & Colorectal cancer. & 63 \\
\hline 18. & 5 Fluoro Uracil & Anti cancer & QESD & Eudragit RS100 & $\begin{array}{l}\text { Enhanced, bioavailability reduction } \\
\text { of side effects }\end{array}$ & 64 \\
\hline 19. & Fluconazole & Anti fungal & QESD & Eudragit L100 & Sustained Release & 65 \\
\hline 20. & Indomethacin & NSAID & QESD & Ethyl cellulose & $\begin{array}{l}\text { Reduce gastric irritation and site } \\
\text { specific targeting }\end{array}$ & 66 \\
\hline 21. & Ketoprofen & NSAID & $\begin{array}{l}\text { Modified QESD using } \\
\text { porogen. }\end{array}$ & Chitosan & Site specific drug targeting. & 67 \\
\hline 22. & Lansoprazole & Proton pump inhibitor & QESD & Eudragit L100, S100 & Avoids degradation in acidic media & 68 \\
\hline 23. & Lornoxicam & osteoarthritis & QESD & Eudragit RS100, RSPO & Sustained drug release & 69 \\
\hline 24. & Lornoxicam & osteoarthritis & QESD & Ethyl cellulose & Sustained drug release & 28 \\
\hline 25. & Meloxicam & Anti-cancer & QESD & Eudragit RS100 & Colon specific drug targeting & 70 \\
\hline 26. & $\begin{array}{l}\text { Metoprolol } \\
\text { succinate }\end{array}$ & & QESD & Ethyl cellulose & $\begin{array}{l}\text { Avoid first pass metabolism and } \\
\text { increase the bio availability }\end{array}$ & 71 \\
\hline 27. & Nicorandil & $\begin{array}{l}\text { Potassium channel } \\
\text { opener }\end{array}$ & QESD & $\begin{array}{c}\text { Eudragit S100,RSPO, } \\
\text { RLPO }\end{array}$ & Controlled release up to $24 \mathrm{hr}$ & 72 \\
\hline
\end{tabular}




\begin{tabular}{|c|c|c|c|c|c|c|}
\hline 28. & Paracetamol & NSAID & QESD & Eudragit S100 & Colon targeted & 73 \\
\hline 29. & Paracetamol & NSAID & QESD & Eudragit RS100 & Controlled release. & 74 \\
\hline 30. & Paracetamol & NSAID & QESD & Eudragit RS100 & Sustain release and colon targeted. & 75 \\
\hline 31. & Piroxicam & NSAID & QESD & $\begin{array}{l}\text { Eudragit RS100, } \\
\text { RL100, S100 }\end{array}$ & $\begin{array}{c}\text { Enhanced solubility and } \\
\text { bioavailability. }\end{array}$ & 76 \\
\hline 32. & Prednisolone & Corticosteroid & QESD & $\begin{array}{l}\text { Ethyl cellulose } \\
\text { Eudragit S100 }\end{array}$ & Colon targeting & 77 \\
\hline 33. & Prednisolone & Corticosteroid & QESD & Eudragit RS100 & $\begin{array}{l}\text { Controlled drug release, } \\
\text { Site specific drug targeting }\end{array}$ & 27 \\
\hline 34. & Resveratol & Ulcerative colitis & $\begin{array}{l}\text { Modified QESD using } \\
\text { porogen } \\
\text { W/O/W }\end{array}$ & Chitosan & Sustained release & 78 \\
\hline 35. & Terbutaline sulphate & Anti- asthmatic & $\begin{array}{l}\text { O/O emulsion solvent } \\
\text { diffusion method }\end{array}$ & Eudragit RS100 & Reduced side effects. & 79 \\
\hline 36. & Valsartan & Anti- hypertensive & QESD & Ethylcellulose & $\begin{array}{l}\text { Controlled drug release, enhanced } \\
\text { stability and reduced side effects }\end{array}$ & 80 \\
\hline
\end{tabular}

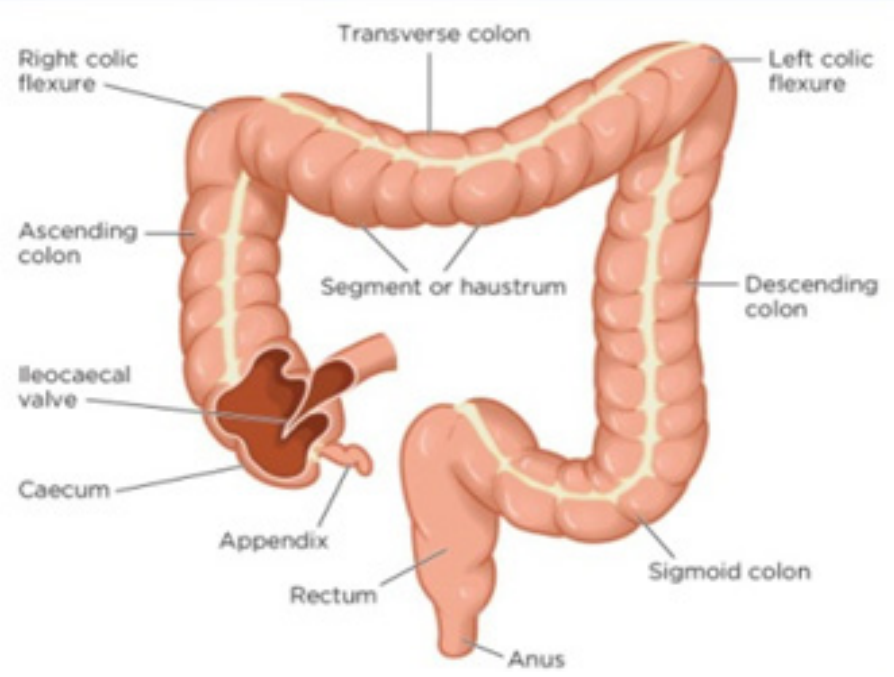

Figure 1: Anatomy of large intestine.

The effect of drug to polymer ratio, stirring speed, time, type and volume of internal phase in the formulation of microsponges areshown in Table $4 .^{27-30}$

\section{Evaluation Parameters}

\section{i Particle size and size distribution}

Particle size and distribution is evaluated by using techniques like zeta seizer, polarizing microscope, optical or electron microscope ${ }^{25}$ and laser light diffractometer. ${ }^{29}$

This study is essential because size of the particles have an effect on the texture and stability of formulation. Particles having diameter of about $10-25 \mu \mathrm{m}$ are found to be free flowing and the particles of diameter greater than 30 impart gritty feeling. ${ }^{25}$

ii Morphology and surface topography of MS

Transmission electron microscope, photon transmission spectroscope, Scanning Electron Microscope is the techniques used for study the morphology of particles.

Most generally used method is SEM analysis where MS are coated with the gold palladium under vacuum. To perform sample imaging

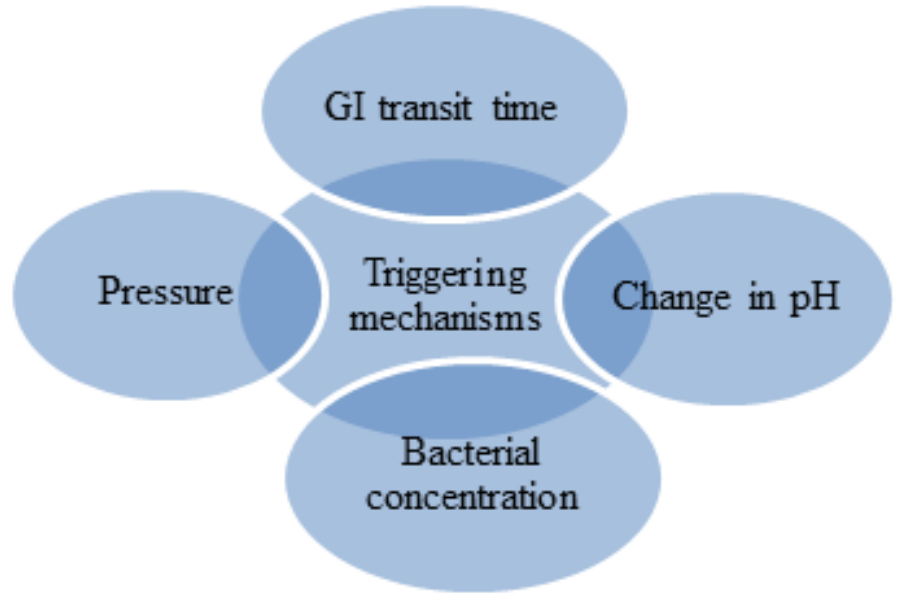

Figure 2: Mechanism of drug release.

in its natural state Environment Scanning Electron Microscopy is used. ${ }^{31}$

iii Porosity: The characteristics feature of MS is its porous nature. Porosity is determined by using two analytical methods, mercury intrusion porosimetry and gas adsorption-desorption method. ${ }^{32}$ The characterization of pores i.e., pore volume and diameter, distribution of pores, total pore surface area etc were carried out. ${ }^{33}$

iv. Determination of True Density: Studies were carried out using Ultra-pycnometer and helium gas and is determined on repeated observations. $^{35}$

v. Determination of drug content, encapsulation efficiency and production yieldMicro sponges are dispersed in a suitable solvent for the entrapped drug to release. After sufficient time the dispersion is centrifuged and the supernatant is analysed with suitable analytical technique and calculated as per formula. This provides the drug content present in the micro sponges.

The exact drug content (\%), loading efficiency (\%), production yield of the MS can be calculated according to the following equations: ${ }^{34}$

Actual drug content $\%=\frac{\text { Mact }}{\mathrm{MMs}} \times 100$

Equation 1 


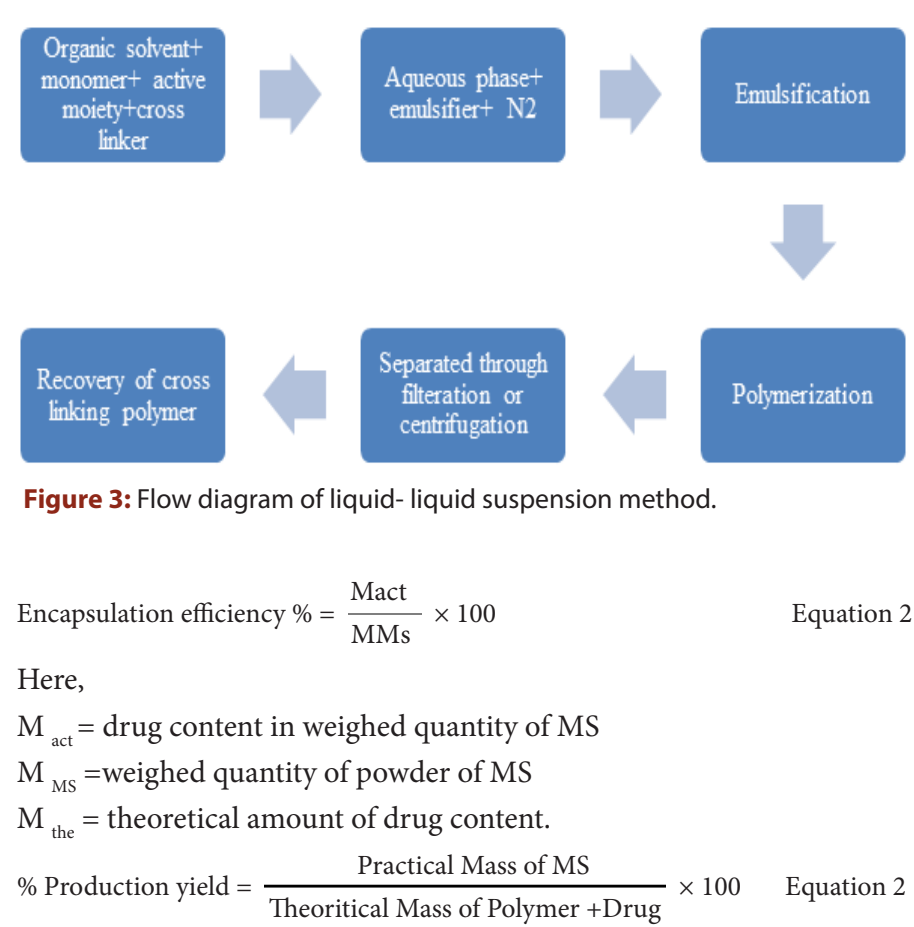

vi. Compatibility studies: The compatibility between the drug and the excipients or adjuncts was studied using Fourier Transform Infrared spectroscopy (FT-IR) and thin layer chromatography (TLC) techniques. ${ }^{36}$ Polymerization that may cause change in crystallinity can be studied using X-ray diffraction (XRD) and thermal analysis of drug carried out using Differential Scanning Calorimetry (DSC). ${ }^{37}$

vii. Polymer or monomer composition: It controls drug release from MS. The polymer forms a layer around the drug which gets thicken upon increasing in polymer concentration this retards the release of impregnated drug. ${ }^{38}$ Different polymers release characteristics can be studied. A graphical plot of percentage drug release against time gives the effect of polymer on rate of release of drug. ${ }^{39}$

viii.Resiliency: This indicates the visco-elastic property of formula (MS). It is the study depends on firmness of final formulation. Increased cross-linking might result in retarding the rate of drug release. ${ }^{40}$ This test claim to be resilient, if there is no sign of disruption observed even after compression of tablet. ${ }^{41}$

ix. Dissolution studies: Dissolution profile of MS is carried out using USP XXIII dissolution apparatus.

Specifications: Modified basket having $5 \mu \mathrm{m}$ stainless steel mesh Speed of the rotation maintained is $150 \mathrm{rpm}$.

The dissolution medium is selected by considering in vitro analysis of the drug. Samples were withdrawn at specified intervals and analysed using suitable analytical method. ${ }^{42}$

x. Kinetics of release: The mode of drug release from the optimised MS formulation can be studied by using the mathematical models as described below: ${ }^{43}$

"Zero Order release kinetics can be measured by using the equation 4 applicable

for modified release dosage forms such as matrix tablets, osmotic systems etc.,

$\mathrm{Q}_{\mathrm{t}}=\mathrm{Q}_{0}+\mathrm{K}_{0} \mathrm{t} \quad$--- equation 4

Where, $Q_{t=}$ amount of the drug at time $t$

$\mathrm{Q}_{0=}$ Initial amount of the drug

$\mathrm{K}_{0=}$ zero order rate constant.
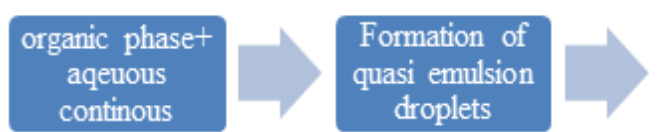

Diffusion of

the organic

solvents

First order release kinetics are measured by using the below equation 5, Applicable for water

soluble drug present in the porous matrix type of dosage form.

$\log C=\log C_{0}-K t / 2.30$--- equation 5

Where, $\mathrm{C}_{0}=$ initial concentration of drug

$\mathrm{C}=$ concentration at time $\mathrm{t}$

$\mathrm{K}=$ first order rate constant".

Higuchi Model: Studied by plotting graph with percentage drug release verses square root of time. This relationship is useful in describing the drug release in modified dosage forms.

$\mathrm{Q}=\mathrm{Kt} 1 / 2$--- equation 6

Where, $\mathrm{K}=$ Higuchi dissolution constant

$\mathrm{Q}=$ Amount of drug release at time $\mathrm{t}$

Hixson-Crowell model: Studied by plotting cube root of percentage drug remaining in matrix versus time. This is applicable for dosage form like tablets, where the dissolution takes place in planes that are parallel to the drug surface.

$\mathrm{W}_{0}^{1 / 3}-\mathrm{W}_{\mathrm{t}}^{1 / 3}=\kappa \mathrm{t}$

Equation 7

$\mathrm{W}_{0}=$ initial amount of drug present in the dosage form

$\mathrm{W}_{\mathrm{t}}=$ remaining amount of drug left in dosage form at time $\mathrm{t}_{\text {; }}$

$\kappa=$ Constant". ${ }^{43}$

Korsmeyer-Peppas Model: This is applicable to study the drug release from the

polymeric dosage forms. Here the drug release is exponentially related to time. ${ }^{42}$

$\mathrm{Mt} / \mathrm{Ma}=\mathrm{Kt}^{\mathrm{n}}$

Equation 8

$\mathrm{Mt} / \mathrm{Ma}=$ Fraction of drug released at time $\mathrm{t}$

$\mathrm{K}=$ Kinetics release rate constant and $\mathrm{n}$ is the release exponent

MDS technique currently used in manufacture of over the counter skin care products, cosmetics and prescription products. ${ }^{44}$ Some of the marketed products commercially available are given in Table $5 .^{45,46}$ MDS applicability for product for oral administration is in research. ${ }^{47}$ Research work on Microsponges drug formulations targeting to colon are summarized in Table 6.

\section{New perspectives using MSD technique}

In recent times, various advances in MDS were made to form nanosponges, nanoferrosponges and siRNA.

Nanosponges have been developed from cyclodextrin (CD's) crosslinked with organic carbonates like dipheyl carbonate. Drugs that are encapsulated in NS were dexamethasone, paciltaxol, flurbiprofen, doxorubicin hydrochloride, 5-fluoro uracil itraconazole, progesterone, nelfinavir mesylate. 
These NS promises in achieving site specific targeting and controlled delivery of drugs. ${ }^{26}$

Nanoferrosponge: Is a novel approach. These are the magnetic nanoparticles having interconnected nanopores of size ranging from 2$100 \mathrm{~nm}$ which serves as a reservoir for various drug moieties. The drug release is controlled by the nanopores which have been manipulated by application of external magnetic field. ${ }^{48}$

Novel therapeutic route for siRNA delivery: RNA interference is a process where short interfering RNA (siRNA) strands suppress gene expression that occurs inside the cell. The authors found densely packed sponge like microparticles is an efficient carrier where synthesis and spontaneous assembly of RNA polymers occur. The Microsponge can deliver approx., half a million siRNA precursors per cell where they observed an improved stability and found relatively effective encapsulation of siRNA. ${ }^{49}$

\section{CONCLUSION}

Colon specific oral drug delivery is an effective formulation strategy that improves the oral bioavailability of acid or/and enzyme labile drugs. In this review, the physiological changes, pathophysiological changes in the microenvironment of colon that surrounds disease site makes targeting of formula/ drug complicated. Using micro particulate system, such as microsponges holds a great potential in enhancing drug targeting, drug uptake and solubility because of its reduced particle size and porous nature. Microsponges have become a rapidly evolving technology. Colon targeting of these Microsponges is a de novo method that provides significant benefit to the patient in terms of safety, efficacy and compliance.

\section{ACKNOWLEDGEMENT}

The authors are thankful to the management of Maharajah's College of Pharmacy for the encouragement and constant support.

\section{CONFLICT OF INTEREST}

The authors declare that there is no conflict of interest among them.

\section{ABBREVIATIONS}

UC: Ulcerative Colitis; MDS: Microsponge delivery system; MS: Microsponges; HPMC: Hydroxypropyl methylcellulose; XRD: X-ray diffraction; DSC: Differential Scanning Calorimetry; QESD: Quasi Emulsion Solvent Diffusion; MPS: Multi particulate system; FT-IR: Fourier Transform Infrared; O/O: Oil in Oil.

\section{REFERENCES}

1. Jose S, Dhanya K, Cinu TA, Aleykutty NA. Multiparticulate system for colon targeted delivery of ondansetron. Indian J Pharm Sci. 2010;72(1):58-64.

2. Patel A, Bhatt N, Patel KR, Patel NM, Patel MR. Colon targeted drug delivery system: A review system. J Pharm Sci Bioscientific Res. 2011;1(1):37-49.

3. Lee SH, Bajracharya R, Min JY, Han JW, Park BJ, Han HK. Strategic Approaches for Colon Targeted Drug Delivery: An Overview of Recent Advancements. Pharmaceutics. 2020;12(1):68-86.

4. Nigam $Y$, et al. Gastrointestinal tract 5: The anatomy and functions of the large intestine. Nursing Times. 2019;115(10):50-3.

5. Philip AK, Philip B. Colon targeted drug delivery systems: A review on primary and novel approaches. Oman Medical Journal. 2010;25(2):79-87.

6. Amidon S, Brown JE, Dave VS. Colon-targeted oral drug delivery systems: Design trends and approaches. AAPS Pharmscitech. 2015;16(4):731-41.

7. Shameem M, Katori N, Aoyagi N, Kojima S. Oral solid controlled release dosage forms: role of $\mathrm{Gl}$-mechanical destructive forces and colonic release in drug absorption under fasted and fed conditions in humans. Pharm Res. 1995;12(7):1049-54

8. Talaei F, Atyabi F, Azhdarzadeh M, Dinarvand R, Saadatzadeh A. Overcoming therapeutic obstacles in inflammatory bowel diseases: A comprehensive review on novel drug delivery strategies. Eur J Pharm Sci. 2013;49(4):712-22.
9. Evans DF, Pye G, Bramely R, Clark AG, Dyson TS. Measurement of gastro intes tinal $\mathrm{pH}$ profile in normal ambulant human subjects. Gut. 1988;29(8):1035-41.

10. Kumari B, et al. An update overview of recent advances on formulation development for colon targeting. IJPSR. 2020;11(4):1571-80

11. Anuj S, Amit JK. Colon targeted drug delivery using different approaches. Int $J$ Pharm Stud Res. 2010;1(1):60-6

12. Mundhe VS and Dodiya SS: Review article: Novel approach for colon targeted drug delivery. Indo American J Pharm Res 2011; 3(1): 158-73.

13. Pradhan SK. Microsponges as the versatile tool for drug delivery system. Int $J$ Res Pharm Chem. 2011;1(2):243-58.

14. Charde MS, Ghanawat PB, Welankiwar AS, Kumar J, Chakole RD. Microsponge A Novel New Drug Delivery System: A Review. Int J Adv Pharm. 2013;2(6):63 70

15. Kumari A, Jain A, Hurkat P Verma A, Jain SK. Microsponges: A pioneering tool for biomedical applications. Crit Rev Ther Drug. 2016;33(1):77-105.

16. Rajeswari S, Swapna V. Microsponges as a Neoteric Cornucopia For Drug Delivery Systems. Int J Curr Pharm Res. 2019;11(3):4-12.

17. Bhanse ND, Shah C, Shah D. Novel And Innovative Strategy: Microsponges Drug Delivery System. Pharma Sci Monit. 2016;7(2):54-73.

18. Kaity S, Maiti S, Ghosh AK, Pal D, Ghosh A, Banerjee S. Microsponges: A novel strategy for drug delivery system. J Adv Pharm Technol Res. 2010;1(3):283-90.

19. Comoglu T, Gonul N, Baykara T. The effects of pressure and direct compression on tabletting of microsponges. Int J Pharm. 2002;242(1-2):191-5.

20. Kumari PU, Mishra SK. A comprehensive review on novel microsponges drug delivery approach. Asian J Pharm Clin Res. 2016;9(1):25-30.

21. Swati KV, Shalini R, Kanchan M, Ashwini C, Eknath P. Microsponge: Comprehensive Review of Application. Int J Pharm Bio Sci. 2013;3(1):214-26.

22. Kumar S, Dalal P, Rao R. Cyclodextrin Nanosponges: A Promising Approach for Modulating Drug Delivery. In Colloid Science in Pharmaceutical Nanotechnology. Intech Open. 2019;1-24.

23. Sareen R, Nath K, Jain N, Dhar KL. Curcumin loaded microsponges for colon targeting in inflammatory bowel disease: Fabrication optimization and in vitro and pharmacodynamic evaluation. Bio Med Res Int. 2014;1-7.

24. Jangde R. Microsponges for colon targeted drug delivery system: An overview. AJP Tech. 2011;1(4):87-93

25. Singhvi G, Manchanda P, Hans N, Dubey SK, Gupta G. Microsponge: An emerging drug delivery strategy. Drug Dev Res. 2019;80(2):200-8.

26. Srivastava R, Pathak K. Microsponges: A futuristic approach for oral drug delivery. Expert Opin Drug Deliv. 2012;9(7):863-78.

27. Sonali, Singh RP, Prajapati SK. Formulation and evaluation of prednisolone loaded microsponges for colon drug delivery: In vitro and pharmacokinetic study. Int J Pharm Sci Res. 2014;5(5):1994-2005

28. Vivekanand $\mathrm{KC}$, et al. Fabrication and Characterization of Lornoxicam Loaded Microsponge Tablets for colon delivery. Acta sci. pharm. sci. 2018;2(10):03-11.

29. Orlu M, Cevher E, Araman A. Design and evaluation of colon specific drug delivery system containing flurbiprofen microsponges. Int J Pharm. 2006;318(1 2):103-17.

30. Kawashima Y, Niwa T, Takeuchi H, Hino T, Ito Y. Control of prolonged drug release and compression properties of ibuprofen microsponges with acrylic polymer, eudragit RS, by changing their intraparticle porosity. Chem Pharm Bull. 1992;40(1):196-201

31. Emanuele AD, Dinarvand R. Preparation, Characterization and Drug Release from Thermo responsive Microspheres. Int J Pharm. 1995;118(2):237-42.

32. JrOrr C. Application of mercury penetration to material analysis. Powder Technol. 1969:3(1):117-23

33. Patil RS, Kemkar VU, Patil SS. Microsponge drug delivery system: A novel dosage form. Am J PharmTech Res. 2012;2(4):227-51.

34. Mohan D, Gupta VR. Microsponge based drug delivery system of voriconazole for fungal infection: Formulation development and in-vitro evaluation. J Drug Deliv Ther. 2019;9(3):369-78

35. Rawat PS, Dhyani A, Singh $V$, Juyal D. A brief review of microsponges: An update. The Pharma Innovation. 2017:6(5, Part C):134-9.

36. Pradhan SK. Microsponges as the versatile tool for drug delivery system. Int J Res Pharm Chem. 2011:1(2):243-6.

37. Kawashima $Y$, Niwa T, Takeuchi $H$, Hino T, Itoh $Y$, Furuyama S. Characterization of polymorphs of tranilast anhydrate and tranilast monohydrate when crystallized by two solvent change spherical crystallization techniques. J Pharm Sci. 1991;80(5):472-8

38. Dua JS, Prasad DN, Hans M, Kumari S. Preparation and Characterization of Itraconazole Microsponges using Eudragit RSPO and Study the Effect of Stirring on the Formation of Microsponges. J Drug Deliv Ther. 2019;9(3-s):451-8.

39. Bodmeier R, Chen H. Preparation and characterization of microspheres containing the antiinflammatory agents, indomethacin, ibuprofen and ketoprofen. Control Release. 1989;10(2):165- 75.

40. Saraf A, Dasani A, Pathan HK. Microsponge drug delivery system as an innovation in Cosmetic world: A Review. Asian J Pharm Sci. 2012;1(2):67-87.

41. Priya VP, et al. Formulation and Characterization of Aspirin loaded modi- 
fied release Microsponges by statistical design. Int $\mathrm{J}$ of Res in Pharmacol Pharmacother. 2017;6(1):65-80.

42. Darekar A, Pawar P, Saudagar RB. A Review on Microsponge as Emerging Drug Delivery System. JDDT. 2019;15;9(3-s):793-801.

43. Suvakanda D, Padala NM, Lilakanta N, Prasanta C. Kinetic modeling on drug release from controlled drug delivery systems. Acta Poloniae Pharmaceutica: Drug Research. 2010;67(3):217-23.

44. Kaity S, Maiti S, Ghosh A, Pal D, Banerjee A. Microsponges: A novel strategy for drug delivery system. J Adv Pharm Technol Res. 2010;1(3):283-90.

45. Jadhav N, Patel V, Mungekar S, Bhamare G, Karpe M, Kadams V. Microsponge delivery system: An updated review, current status and future prospects. J Sci Innovative Res. 2013;2(6):1097-10.

46. Kumar R, Bhowmick M, Dubey B. Polymeric Microsponge Technology: An Overview on Highly Cross-linked Porous Spherical Particles for Topical Delivery. Inventi Impact: NDDS. 2012;2012(2):1-7.

47. Sharma, Sharma A, Kaur C. Microsponges: As a topical drug delivery system. Int J Pharm Sci Res. 2020;11(2):524-34.

48. Hu SH, LiuTY, Liu DM, Chen SY. Nano-ferrosponges for controlled drug release. J Control Release. 2007;121(3):181-9.

49. Grabow W, Jaeger L. SiRNA delivery: Loaded-up microsponges. Nature Mater. 2012;11(4):268-9.

50. Shah $\mathrm{H}$, Patel K. Formulation and evaluation of controlled release colon targeted micro sponge of Aceclofenac. Pharma Innovation. 2014;3(10, Part B):81-7.

51. Dev A, Dwivedi J, Momin M. Quality by Design based formulation and evaluation of acyclovir microsponges. J Drug Deliv Ther. 2019;9(1):54-60.

52. Abdellatif AA, et al. A novel controlled release microsponges containing Albendazole against Haemonchus contortus in experimentally infected goats. J Drug Deliv Ther. 2018;43:469-76.

53. Janakidevi S, Ramanamurthy KV. Development of Colon-targeted Microspong es for the Treatment of Inflammatory Bowel Disease. Indian J Pharm Sci 2018;80(4):604-9.

54. Saini R, Singh SK, Verma PR. Evaluation of carvedilol-loaded microsponges with nanometric pores using response surface methodology. J Exp Nanosci. 2014;9(8):831-50.

55. Alhammid SN. Enhancement of the solubility and the dissolution rate of candesartan cilexetil using microsponge technology. Asian J Pharm Clin Res. 2018;11(9):385-90

56. Bhatia M, Saini M. Formulation and evaluation of curcumin microsponges for oral and topical drug delivery. Prog Biomater. 2018;7(3):239-48.

57. Janakidevi S, Ramanamurthy K. Design of a novel colon targeted microsponges loaded with diclofenac sodium using three different polymers. Int Res J Pharm. 2018;9(4):10-9

58. Jain $V$, Singh R. Dicyclomine-loaded Eudragit $\circledast$-based microsponge with potential for colonic delivery: Preparation and characterization. Trop J Pharm Res. 2010;9(1):67-72.

59. Jain $V$, Jain $D$, Singh $R$. Factors effecting the morphology of eudragit S-100 based microsponges bearing dicyclomine for colonic delivery. J Pharm Sci. 2011;100(4):1545-52.

60. Ivanova N, DiFranco C, Trapani A, Petkova V, Dimitrov M. Synthesis and Characterization of Diltiazem Loaded Eudragit Rs 100Microsponges. World J Pharm Pharm Sci. 2017;6(6):32-42.

61. Taghi HS, Abdulbaqi MR, Jabar EG. Enhancement Solubilization of Dutasteride using Microsponge Formulation. Int J Drug Deliv Technol. 2020;10(1):60-7.

62. Othman MH, Zayed GM, El-Sokkary GH, Ali UF, Abdellatif AA. Preparation and evaluation of 5-fluorouracil loaded microsponges for treatment of colon cancer
J Cancer Sci Ther. 2017;9(1):307-20.

63. Gupta A, Tiwari G, Tiwari R, Srivastava R. Factorial designed 5-fluorouracil-loaded microsponges and calcium pectinate beads plugged in hydroxypropyl methylcellulose capsules for colorectal cancer. Int J Pharm Investig. 2015;5(4):234 46.

64. Ali AU, El-Badry M, Elfaham TH. Formulation of 5-Fluorouracil Microsponges As Colon Targeted Delivery System using 32 Factorial Design. Bull Pharm Sci. Assiut. 2018;41(1):31-44.

65. Hans M, Dua JS, Prasad DN, Sharma D. Formulation and Evaluation of Fluconazole Microsponge using Eudragit L 100 by Quasi Emulsion Solvent Diffusion Method. J Drug Deliv Ther. 2019;9(3-s):366-73.

66. Parameshwar K, Jha SK, Diyya M. Design and development of oral dosage form for colon specific drug release of indomethacine. World J Pharm Pharm Sci. 2017;6(8):2158-83.

67. Rathore C, Jain N, Garg N, Mahindroo N, Sharma G, Negi P. PolysaccharideMicrosponge Based Matrix Tablet For Colon Targeting Of Ketoprofen: In vitro and in vivo Evidence. Int J Pharm Sci Res. 2017;8(10):4250-60.

68. Imran T, Sadhana S. Formulation and development of microsponges based delayed release dosage form of lansoprazole. Int J Pharm Sci Res. 2018;9(2):82431.

69. Thireesha B, Prasad AR, Peter PL. Formulation and evaluation of lornoxicam microsponges using eudragit RS 100 and Eudragit RSPO. Asian J Pharm Clin Res. 2018;11(10):217-21.

70. Srivastava R, Kumar D, Pathak K. Colonic luminal surface retention of meloxicam microsponges delivered by erosion based colon-targeted matrix tablet. Int J Pharm. 2012;427(2):153-62.

71. Jain P, Darwhekar GN, Khan F, Kukde D, Sharma V. Formulation and evaluation of colon specific tablet containing microsponges of metoprolol succinate. Int J Pharm Life Sci. 2015;6(12):4851-6

72. Patel S, Patel M. Formulation and Evaluation of microsponges based nicorandil sustained release tablet. J Sci Res. 2017;9(3):285-96.

73. Jain $V$, Singh R. Design and characterization of colon-specific drug delivery system containing paracetamol microsponges. Arch Pharm Res. 2011;34(5):73340.

74. Jain V, Singh R. Development and characterization of Eudragit RS 100 loaded microsponges and its colonic delivery using natural polysaccharides. Acta Pol Pharm. 2010;67(4):407-15

75. Mishra MK, Shikhri M, Sharma R, Goojar MP. Optimization, formulation development and characterization of Eudragit RS 100 loaded microsponges and subsequent colonic delivery. Int J Drug Discov Herb Res. 2011;1(1):8-13.

76. Rajab NA, Jawad MS. Formulation and in vitro evaluation of piroxicam microsponge as a tablet. Int J Pharm Pharm Sci. 2016;8(2):104-4.

77. Kumari A, Jain A, Hurkat P, Tiwari A, Jain SK. Eudragit S100 coated microsponges for Colon targeting of prednisolone. Drug Dev Ind Pharm. 2018;44(6):902-13.

78. Gandhi H, Rathore C, Dua K, Vihal S, Tambuwala MM, Negi P. Efficacy of resveratrol encapsulated microsponges delivered by pectin based matrix tablets in rats with acetic acid-induced ulcerative colitis. Drug Dev Ind Pharm. 2020;46(3):365-75.

79. Biswajit B, et al. Development and characterization of terbutaline sulphate microsponge and its colonic delivery by compression coated tablets. Pharm Ana Acta. 2013;14:2.

80. Desavathu M, Pathuri R, Chunduru M. Design, development and characterization of valsartan microsponges by quasi emulsion technique and the impact of stirring rate on microsponge formation. J Appl Pharm Sci. 2017;7(1):193-8.

Article History: Submission Date : 06-06-2020; Revised Date : 23-07-2020; Acceptance Date : 31-08-2020.

Cite this article: Hari K, Prathyusha SS, Vasavi G. Microsponges: A De Novo Method for Colon Targeted Oral Drug Delivery. Int. J. Pharm. Investigation, 2020;10(3):237-45 